\title{
Review on the Efficacy, Safety and Clinical Applications of Polihexanide, a Modern Wound Antiseptic
}

\author{
N.-O. Hübner A. Kramer \\ Institute of Hygiene and Environmental Medicine, Ernst Moritz Arndt University Greifswald, Greifswald, Germany
}

\section{Key Words}

Polihexanide, efficacy · Polihexanide, safety · Polihexanide, toxicology $\cdot$ Antiseptic $\cdot$ Wounds

\begin{abstract}
Infected wounds are still one of the great challenges in medicine. In the last decade, it has become increasingly clear that antimicrobial chemotherapy is limited by the spread of antimicrobial resistance. Fortunately, new, highly effective antiseptic substances with a broad antimicrobial spectrum are available, so local treatment is expected to get increasingly more important in wound therapy. This paper reviews the antiseptic agent polihexanide (polyhexamethylene biguanide, $\mathrm{PHMB}$ ), one of the most promising substances available today, from a clinical point of view, focusing on efficacy, safety and clinical applications.

Copyright $\odot 2010$ S. Karger AG, Basel
\end{abstract}

\section{Introduction}

The topical application of substances on wounds to prevent or treat putrefaction is as old as medicine. John Pringle was the first who used the term 'antiseptic' for these substances, and therefore set the definition still used today. After the great discoveries of Joseph Lister and the advances in chemistry, antiseptics became the standard for treatment of wounds in the late 19th century. Despite the high toxicity of the substances used at that time, they did not lose their importance before the development of antibiotics in the middle of the 20th century. Today, antimicrobial chemotherapy is increasingly complicated by progressive antimicrobial resistance [1]. The treatment of infected wounds is therefore still one of the great challenges in medicine. Fortunately, new, highly effective antiseptics are available that lack the drawbacks of the old ones from the past. Modern antiseptics can therefore be the alternative to antibiotic treatment that is so much needed, provided that they combine a broad antimicrobial spectrum with low toxicity, high tissue compatibility, low or missing adsorption and good applicability. Current guidelines therefore recommend the application of wound antiseptics as long as an infection is confined to the wound and has not spread systemically. Additional antimicrobial chemotherapy should be limited to situations with systemic involvement or cases where single antiseptic treatment is not expected to be successful [2].

This paper reviews the antiseptic polihexanide (polyhexamethylene biguanide, $\mathrm{PHMB}$ ), one of the most promising substances available today, from a clinical point of view, focusing on efficacy, safety and clinical applications.

\section{KARGER}

Fax +41613061234

E-Mail karger@karger.ch

www.karger.com (c) 2010 S. Karger AG, Basel

$1660-5527 / 10 / 0237-0017 \$ 26.00 / 0$

Accessible online at:

www.karger.com/spp
Nils-Olaf Hübner, MD

Institute of Hygiene and Environmental Medicine

Ernst Moritz Arndt University Greifswald, Walther Rathenau Strasse 49a DE-17489 Greifswald (Germany)

Tel. +49 383451 5546, Fax +49383451 5541, E-Mail nhuebner@uni-greifswald.de 
Only Cosmocil PGTM (Arch Chemicals, UK) corresponds in its specification with the parameters which are defined in the DAC monograph for PHMB; Vantocil $\mathrm{IB}^{\mathrm{TM}}$, Cosmocil CQ $\mathrm{CQ}^{\mathrm{TM}}$ (both Arch Chemicals) as well as Lonzabac BG ${ }^{\mathrm{TM}}$ (Laboratoire PAREVA, France) correspond only incompletely with the DAC monograph.

\section{Actions}

\section{Mode of Action}

Being a strong base, $\mathrm{PHMB}$ interacts with acidic, negatively charged phospholipids in the bacterial membrane, leading to increased fluidity, permeability and loss of integrity, followed by the death of the organism [3-6]. The maximum activity occurs at a $\mathrm{pH}$ value of between 5 and $6[7,8]$. PHMB is also transferred to the cytoplasm, where it leads to disruption of the bacterial metabolism. Neutral phospholipids on the other hand are little or not affected by PHMB $[9,10]$. This is commonly seen as the main reason for the low toxicity of PHMB against human cells and its high therapeutic range [11].

Furthermore, presumably as a result of the interaction with the cell membrane, PHMB blocks microbial attachment to surfaces, as shown for dental plaque and for the preoperative eye antiseptic $[12,13]$. PHMB is able to significantly eliminate artificial plaques of fibrin in vitro [14], which is of clinical relevance, because plaques can impair the self-cleansing of the wound. This corresponds to clinical data [15]. For details see Kaehn [16] in this supplement.

\section{Interactions}

PHMB is compatible with acids, quaternary ammonium compounds and neutral detergents but incompatible with anionic detergents, soaps and alkyl sulfates (e.g. ammonium lauryl sulfate). Strong inorganic bases and complex phosphates lead to precipitation. PHMB does not affect stainless steel or anodized aluminium, but copper and some types of rubber are delicate [11]. Ansorg et al. $[17,18]$ were able to show that the antibacterial effect of PHMB is abolished by mucin in concentrations of 0.5 and $1 \%$, which is even lower than the mucin concentrations in healthy nasal secretions. PHMB is completely neutralized in the presence of chondroitin sulfate [19], which obstructs the use of polihexanide in situations in which mucin or chondroitin sulfate load is expected.

Polihexanide has a greater antimicrobial efficacy than chlorhexidine under both clean and dirty conditions [20]. Its antimicrobial effect is not impaired even with high loads of blood or albumin, but exceeds the efficacy of PVP-iodine in situations with high blood load [20, 21]. Most importantly, PHMB was shown to maintain its antibacterial effect in human wound fluid and human tissue [22-24].

Hübner et al. [25] assessed the antimicrobial efficacy of the combined use of antiseptics and antibiotics in vitro. This is of particular interest, because the combined use of local antiseptics and systemic antibiotic therapy is clinical practice. While polihexanide is not adsorbed and therefore does not interact systemically (see above), antibiotics do reach the wound and can interact locally. Using microtiter assays, they were able to show that PHMB acted synergistically with commonly used antibiotics, while chlorhexidine did not [26].

\section{Antimicrobial Efficacy and Resistance}

Due to its nonspecific, strong interaction with negatively charged phospholipids, PHMB has a broad antimicrobial spectrum, including Gram-positive and Gramnegative bacteria, plaque-forming and biofilm-building bacteria, spore-forming bacteria (but not bacterial spores), intracellular bacteria such as chlamydiae and mycoplasma, and fungi including Candida spp. as well as Aspergillus spp. [13, 21, 24, 27-34]. PHMB is able to inactivate HIV-1 [35] and HSV [36] in vitro.

The minimal microbiocidal concentrations of PHMB are reported as follows: Staphylococcus aureus: $0.1 \mu \mathrm{g} / \mathrm{ml}$, Bacillus subtilis: $0.5 \mu \mathrm{g} / \mathrm{ml}$, Streptococcus faecalis, Streptococcus lactis, Escherichia coli and Enterobacter cloacae: $5 \mu \mathrm{g} / \mathrm{ml}$, Pseudomonas aeruginosa and Saccharomyces cerevisiae: $25 \mu \mathrm{g} / \mathrm{ml}$ [11]. In 10\% fetal bovine serum, PHMB at a concentration of $100 \mu \mathrm{g} / \mathrm{ml}$ was shown to achieve a $3 \log _{10}$ reduction of $S$. aureus and at a concentration of $90 \mu \mathrm{g} / \mathrm{ml}$ a similar reduction of $E$. coli after 30 min contact times in each case [24].

A reduction of $>5 \log _{10}$ after 5 min contact time is achieved with a concentration of $0.02 \%(200 \mu \mathrm{g} / \mathrm{ml})$ against $S$. aureus, E. coli, E. faecium, P. aeruginosa and $C$. albicans under clean and dirty conditions $(0.3 \%$ blood and $0.3 \%$ albumin load) [24]. Despite the incompatibility with chondroitin sulfate, a $0.005 \%(50 \mu \mathrm{g} / \mathrm{ml})$ concentration of PHMB was shown to achieve a $3 \log _{10}$ reduction against $E$. coli and $S$. aureus in the presence of cartilage [21].

Furthermore, $\mathrm{PHMB}$ was not only shown to completely eliminate elastase-expressing $P$. aeruginosa that degraded wound fluid proteins as well as human skin during infection ex vivo, but inhibited consequent protein degradation $[22,23]$. 
A $0.02 \%$ solution of PHMB effectively removed an artificial $P$. aeruginosa biofilm from plastic slides in a contact time of $60 \mathrm{~min}$ in vitro [33]. Compared to Ringer solution and saline, a surfactant PHMB solution achieved a significant reduction $(\mathrm{p}<0.001)$ against a $P$. aeruginosa biofilm on silicone after a 24-hour exposure time [37]. This is further supported by results from Pietsch and Kraft [32]. Similarly, Brex et al. [38] reported data on the effect of PHMB as a mouth rinse on de novo dental biofilm formation in vivo. Using a double-blind randomized controlled clinical setting, they compared a PHMB-containing mouth rinse solution (Prontolind ${ }^{\circledR}$ ) with a $0.2 \%$ chlorhexidine rinse as the positive control and with $0.9 \%$ saline solution $(\mathrm{NaCl})$ as the negative control. While limited by the small number of participants $(n=6$ in each study group), they were able to show that the PHMB formulation showed a similar antibacterial effect and reduction of the de novo biofilm formation in the oral cavity over a test period of 4 days as chlorhexidine [38].

PHMB is effective against Acanthamoeba keratitis in concentrations as low as $0.025 \%(250 \mu \mathrm{g} / \mathrm{ml})$ as single substance as well as in combination with propamidine and neomycin [39]. PHMB was found to be cysticidal against Acanthamoeba at 9.4, 5.6 and $2.4 \mu \mathrm{g} / \mathrm{ml}$ after 8 , 24 or $48 \mathrm{~h}$ contact times, respectively [40]. When used to combat Acanthamoeba keratitis, the therapist should keep in mind that some primary resistances of Acanthamoeba to PHMB are reported in the literature $[41,42]$. But until now, no bacterial resistances to PHMB have been reported and are not to be expected due to its nonspecific mode of activity [6].

Because polihexanide binds to cellular surfaces, it also has a sustained effect over hours [43, 44].

\section{Tolerability}

PHMB is well tolerated when used topically on skin, eyes [45], nose, ciliated epithelium [46] and wounds [11].

\section{Allergic Risks}

PHMB showed neither sensitizing nor photosensitizing effects in animal tests. In contrast to chlorhexidine that is regularly reported to lead to late-onset hypersensitivity, eczema and even to severe anaphylactic reactions [47-50], PHMB seems to carry only a slight allergic risk and remains an uncommon contact allergen [51-53].

Two cases of a possible anaphylactic reaction to $\mathrm{PHMB}$ without confirmation in the prick test were reported by Olivieri et al. [54], another case was reported by Ferrarini et al. [55] and Schnuch et al. [56]. Despite the widespread use of PHMB as a preservative in cosmetics and personal care products, the frequency of sensitization remains low and no further anaphylactic reactions are reported in the literature [56]. In an investigation in patients with chronic wounds, no sensitization to PHMB was identified, whereas the rates of contact sensitization to PVP-iodine were $20 \%$, to balsam of Peru $15.6 \%$, to fragrance mix $11.1 \%$, to colophony $8.8 \%$ and to potassium dichromate $6.7 \%[57]$.

\section{Toxicity}

\section{Acute Toxicity}

PHMB is classified as 'practically nontoxic', based on the low oral toxicity of $5 \mathrm{~g} / \mathrm{kg}$ in rat [58]. The therapeutic index of PHMB (200.3), calculated as a quotient of the $\mathrm{LD}_{50}$ (rat) and the MIC against $P$. aeruginosa, is more than 200-fold that of chlorhexidine (0.9) [59].

PHMB was shown to positively affect skin microcirculation [60].

Application of very high doses of PHMB can trigger fever and a generalized exanthema [61]. The intraperitoneal application of a $0.04 \%$ solution of PHMB led to local vasodilatation and systemic hypotension in mice [62]. The underlying principle assumed by the authors was the possible promotion of nitric oxide liberation, potassium channel activation and vasodilation that would result in hypotension [63].

The minimum concentration for irritation for skin is reported to be well above 5\% (rats) and over 25\% for eye (rabbits) [61]. PHMB is compatible with nasal mucosa at a concentration of $0.02 \%$ [46].

\section{Chronic Toxicity}

The NOEL was found to be $200 \mathrm{mg} / \mathrm{kg} /$ body weight/ day. Chronic oral intake of $100 \mathrm{mg} / \mathrm{kg} /$ body weight/day was tolerated over 2 years without adverse reactions [64, 65].

\section{Adsorption}

No uptake of PHMB from intact skin and wounds could be proved (detection limit: 10 ppm) [34, 64].

\section{Genotoxicity, Reproductive and Developmental}

Toxicity

No indication of any mutagenicity or carcinogenicity was found in vitro or in vivo [11]. Administration of up to $40 \mathrm{mg} / \mathrm{kg} /$ body weight/day (p.o.) was not teratogenic in mice. Similarly, the administration of up to $8 \mathrm{mg} / \mathrm{kg} /$ body weight/day showed no teratogenicity or embryotoxic ef- 
fects in rabbits, but the oral administration of a $0.04 \%$ solution of PHMB in combination with polyethylene glycol was embryotoxic at a dose of $32 \mathrm{mg} / \mathrm{kg} /$ body weight/day. Oral administration of $100 \mathrm{mg} / \mathrm{kg} /$ body weight/day was embryotoxic in rats, and intraperitoneal application of 10 $\mathrm{mg} / \mathrm{kg} /$ body weight/day showed teratogenicity $[11,66]$.

There is no evidence of relevant adverse effects on the male or female reproductive organs from chronic carcinogenicity studies, subacute toxicity studies and 2-year treatment studies with PHMB. Chronic oral toxicity studies in dogs showed reduced testis weights and testicular tubular degeneration in individual animals at the highest dose, producing overt signs of toxicity only.

In 2004, the US Environmental Protection Agency (EPA) reviewed the database on mice, rats and rabbits for prenatal developmental toxicity as well as reproductive toxicity of PHMB. No evidence of reproductive and developmental toxicity from any of the publicly available and well-controlled animal studies submitted for PHMB to the Agency was described. Nevertheless, the teratogenic effect in rats was mentioned in the patient information of Lavasept ${ }^{\circledR}$ (see above), but the reliability of the source could not be confirmed by the EPA [67].

Interestingly, the dose levels for maternal toxicity in both animal species is lower than or equal to the developmental toxicity, indicating that developmental toxicity at the high dose of PHMB was related to maternal toxicity. There was also no concern with regard to developmental neurotoxicity and no quantitative or qualitative evidence of increased susceptibility of the fetus following in utero exposure. Fertility was not obviously affected in rats.

In man, no chronic health effects associated with PHMB exposure were reported in any of the databases or in epidemiological studies. There was also no evidence of an impairment of reproductive and developmental performance in humans. Systemic exposure to PHMB was considered to be negligible, and the poor bioavailability of PHMB is well known. These facts and its molecular weight make transplacental transfer or transfer into milk very unlikely [68-73].

\section{Ecotoxicology}

In the OECD closed-bottle test, PHMB is only partly biodegradable (13.5\% in 28 days), but wild-type isolates of Sphingomonas spp. are able to degrade PHMB. The $\mathrm{LC}_{50}$ for rainbow trout is $3.2-13 \mathrm{mg} / \mathrm{l} / 96 \mathrm{~h}[11,74,75]$.

Cytotoxicity and Tissue Toxicity in vitro and ex vivo

In vitro results from cell culture tests and explant tests show that PHMB has remarkable low cytotoxicity.
The $\mathrm{IC}_{50}$ in FL-cell culture is $30 \mathrm{mg} / \mathrm{l}$, for cress 800 $\mathrm{mg} / \mathrm{l}$ [59] and for murine fibroblasts after $30 \mathrm{~min}$ contact time with PHMB in 10\% fetal bovine serum $136 \mathrm{mg} / \mathrm{l}$ [24].

Kallenberger et al. [76] concluded after performing extensive tests including explantation test with rat heart tissue and fetal rat humeri as well as tests on wound healing in a guinea pig model that PHMB is superior to PVP-iodine in terms of tissue compatibility but is incompatible with cartilage. Müller and Kramer [78], on the other hand, did not see toxic effects on cartilage ex vivo when $\mathrm{PHMB}$ was used in concentrations below 0.005\%.

$\mathrm{PHMB} / \mathrm{macrogol}$ solution was found as the agent of choice, when comparing the tissue compatibility of a $\mathrm{PHMB} / \mathrm{macrogol}$ combination with 8 antiseptics (including PVP-iodine and chlorhexidine) and placebo in peritoneal explants and peritoneum in situ in the experimental animal with subsequent extraction and cultivation of the explants as a model for chronic or deep wounds [78]. These results were just recently confirmed by Hirsch et al. [79], who found PHMB to be superior to different PVP-iodine solutions in terms of antimicrobial efficacy and tolerability. Werthen et al. [23] demonstrated by SEM analysis that $\mathrm{PHMB}$ does not affect connective tissue components of the dermis, such as collagen fibers and elastin. In contrast, PHMB has a stimulating effect on the proliferation of human keratinocytes in concentrations up to $2 \mu \mathrm{g} / \mathrm{ml}$, but inhibits cell proliferation or is directly cytotoxic in higher concentrations in vitro [80]. Also, PHMB inhibits the formation of nitrogen and oxygen radicals that are known to promote inflammation in vitro $[81,82]$.

The cytotoxicity and antimicrobial efficacy of PHMB are greatly influenced by additives that are commonly used in commercially available solutions containing PHMB as the active substance to reduce its surface tension [76]. Müller et al. [29], comparing the $\mathrm{IC}_{50}$ for a combination containing PHMB with PEG 4000 (macrogol) $(255 \mu \mathrm{g} / \mathrm{ml})$ and PHMB with undecylenamidopropyl betaine $(353 \mu \mathrm{g} / \mathrm{ml})$, found a difference of approximately $28 \%$ after 5 min exposure time in each case. Interestingly, this difference was even more pronounced with the highest tested concentration of $500 \mu \mathrm{g} / \mathrm{ml}$ PHMB and the shortest contact time of $1 \mathrm{~min}$, when the combination $\mathrm{PHMB} /$ macrogol was twice as toxic as the combination $\mathrm{PHMB} /$ betaine, but became smaller with longer contact times and lower concentrations. 


\section{Efficacy}

\section{Relation of Effectiveness and Tissue Compatibility}

The biocompatibility index (BI) has been described and validated from in vitro experiments as a new tool for predicting the suitability of antiseptic agents: in parallel, the antibacterial activity of the test substance against $S$. aureus/E. coli and its cytotoxicity on cultured murine fibroblasts are measured in the presence of cell culture medium containing $10 \%$ fetal bovine serum over $30 \mathrm{~min}$ at $37^{\circ} \mathrm{C}$ [24]. The $\mathrm{BI}$ is defined as the ratio of the concentration at which $50 \%$ of the murine fibroblasts are damaged and the microbicidal effect producing at least $3 \log _{10}(99.9 \%)$ reduction. The smaller the BI, the more inconvenient the antibacterial effect in relation to the cytotoxicity, with a $\mathrm{BI}<1$ indicating a toxicity that exceeds the antiseptic effect. This combined assessment of cellular cytotoxicity and antimicrobial activity has been shown to be a good predictor of the clinical effect. In this assay, PHMB performs remarkably well $\left(\mathrm{BI}_{\text {S. aureus }}=1.36\right)$ and is only outclassed by the commercially available combination of octenidine dihydrochloride/phenoxyethanol (Octenisept ${ }^{\circledR}$, Schülke \& Mayr, Norderstedt, Germany) with a $\mathrm{BI}_{S \text {. aureus }}=2.11$. Other antiseptics such as chlorhexidine $(\mathrm{BI}=0.98)$ or PVP-iodine $(\mathrm{BI}=0.68)$, on the other hand, show a much inferior profile, while silver sulfadiazine was not assessable at all due to its high toxicity but lack of antibacterial effect [11, 24, 29, 77].

This was confirmed in a co-culture of $\mathrm{HaCaT}$ keratinocytes and S. aureus, in which $1 \mu \mathrm{g} \mathrm{PHMB} / \mathrm{ml}$ inhibited the bacterial growth, whereas the cells were impaired in their growth [82].

\section{Tissue Compatibility in vivo/Effects on Wound}

\section{Healing in Animal Models}

Tissue compatibility of PHMB in vivo has been extensively studied in different animal models. One of the first teams to assess the influence of PHMB on wound healing in animals was Kallenberger et al. [76]. They compared wound closure and histological findings in artificial wounds in guinea pigs after treatment with polihexanide, PVP-iodine and placebo (Ringer's solution and dry strap), respectively. Histomorphometric evaluation revealed that PHMB in concentrations of $0.02 \%$ (in combination with polyethylene glycol) has a tissue compatibility that greatly outclasses that of 5\% PVP-iodine. Comparison of wound healing revealed that bactericidal concentrations of PHMB are significantly superior to PVP-iodine and to dry strap control treatment.

Review on the Efficacy, Safety and Clinical Applications of Polihexanide
Accordingly, a solution containing 0.02\% PHMB and $0.001 \%$ polyethylene glycol did not lead to irritation in the in vivo hen's egg chorioallantoic membrane assay (HETCAM assay) after 5 min exposure time, while a solution containing $0.04 \%$ PHMB and polyethylene glycol led to slight hyperemia and some hemorrhage, but the single application of $0.04 \%$ PHMB did not $[41,83]$.

PHMB at concentrations $\geq 0.025 \%$ shows cytotoxic effects on peritoneum and signs of systemic toxicity in guinea pigs $[84,85]$. Similarly, treatment with a solution containing $0.02 \%$ PHMB (in combination with polyethylene glycol) led to pronounced chronic and erosive granulating synovialitis, a giant-cell reaction including dystrophic calcifications on cartilage, in chinchilla hybrid rats [86].

Possibly the most pioneering study on tissue compatibility and wound healing of PHMB in an animal model in recent years was published by Kramer et al. [87]. They compared the influence of preparations based on PHMB and octenidine versus placebo (Ringer's solution) in experimental superficial aseptic skin wounds $(n=108)$ in piglets using a double-blind, randomized, stratified, controlled, parallel-group design and computerized planimetry as well as histopathological methods to compare wound healing and tissue compatibility. Frankly, no significant histological differences could be verified at any time between the 3 groups, but wound contraction was promoted significantly more by polihexanide than by placebo or octenidine. Consequently, complete wound closure was achieved significantly earlier using polihexanide than with placebo ( 22.9 vs. 24.1 days, $\mathrm{p}<0.05)$. This was attributed by the authors to the better tolerance of $\mathrm{PHMB}$, as shown in vitro.

\section{Clinical Applications}

\section{Clinical Data}

Products that are suitable for eye antiseptics are also known to be effective and tolerable for wound treatment without inhibiting the healing process and vice versa. Therefore, some results regarding eye antisepsis are briefly presented. 0.02\% PHMB is effective against Acanthamoeba keratitis as pure active agent $[88,89]$ as well as in combination with other substances like propamidine, hexamidine, or neomycin [90-100]. Therefore, PHMB is considered to be the first-choice therapy for Acanthamoeba keratitis. Numerous studies proved acanthamoebicidal efficacy and good clinical outcome with prompt local treatment [39, 40, 88-102]. On the other hand, treat-

Skin Pharmacol Physiol 2010;23(suppl 1):17-27 
ment failures have been reported, particularly when presentation was late, in cases of deep stromal infection, or in rare cases of primary PHMB resistance of Acanthamoeba strains [41, 42, 96, 103]. 0.02\% polihexanide is also effective against Nocardia asteroides keratitis (MIC 0.01\%) [104] and Fusarium keratomycosis in rabbits [105]. In addition, polihexanide has shown superior efficacy and a sustained effect compared to povidone iodine when used as preoperative antiseptic for cataract surgery [12].

Wound Antisepsis. Different authors have published data on the clinical use of PHMB on wounds either as case reports or as controlled studies.

\section{Controlled Studies}

Schmit-Neuerburg et al. [106] investigated the effect of dressings soaked with $0.04 \%$ PHMB or Ringer's solution and changed once daily on contaminated wounds in a prospective, controlled, double-blind trial including 85 patients. Treatment with polihexanide resulted in better wound healing, in significantly faster reduction of Grampositive organisms and showed better tissue compatibility than Ringer's solution.

The most comprehensive clinical data from a retrospective, multicentre, randomized controlled cohort study have been published by Roth and colleagues: a total of 7,862 patients derived from a rural-agricultural setting with dirty contaminated wounds were randomly assigned to four groups after wound debridement. Patients in each group received a single wound cleansing using Ringer's solution, hydrogen peroxide, polihexanide $0.04 \%$ or PVP-iodine, respectively. The lowest frequency of postoperative wound infection was observed in patients where the wound was treated with PHMB after wound debridement. Odds ratios revealed a 7-fold higher risk of infection for wounds treated with hydrogen peroxide, a 3.7-fold higher risk for Ringer's solution and a 3.2-fold risk for wounds treated with PVP-iodine, compared to PHMB. These differences in infection rates were significant $(p<0.001)$. These findings are consistent with results published earlier [107, 108] and later [109] by the same group. The authors concluded that PHMB-based wound antiseptics can be recommended for use for the management of traumatic contaminated wounds [110].

Andriessen and Eberlein [111] published data from a retrospective, controlled analysis of the clinical efficacy of PHMB solution compared to Ringer's solution or saline in venous leg ulcers. Wounds treated with $\mathrm{PHMB}$ solution healed significantly faster and in more cases $(97$ vs. $89 \%$, mean time to healing 3.31 vs. 4.42 months, 6 months observation period, Kaplan-Meier mean estimated $\mathrm{p}<0.0001)$. Moreover, risk of infection has been shown to be lower in patients treated with PHMB.

Daeschlein et al. [15] compared the outcome of treatment of poorly healing decubitus ulcers with mesh grafts. Wound beds were divided into 3 areas and pretreated with either undiluted PVP-iodine solution, $1 \%$ silver nitrate solution or $0.04 \%$ PHMB solution. After 7 days of application, the histological results showed deep necrosis with extended oedema plus fibrin discharge in tissue samples treated with PVP-iodine solution or silver nitrate, but absence of necrosis or a markedly reduced wall of necrosis in the deep granulation tissue after treatment with $\mathrm{PHMB}$ in all 4 patients included. Clinically, the area treated with $\mathrm{PHMB}$ showed the best results in terms of epithelialization. Assured by these results, the authors extended their study by a second, prospective clinical trial including 14 patients with second-degree burn wounds that could not be primarily treated with skin grafts due to inadequate wound bed conditions. Patients underwent brush debridement in combination with $0.04 \%$ PHMB under general anaesthesia and wounds were covered with dressings soaked in $0.04 \%$ PHMB and changed twice daily. In all patients, wounds epithelialized without any further debridement after an average of 10 days. A remarkable freedom from pain and comfort was reported by the patients [15].

Valenzuela and Perucho [112] published data from a randomized, non-blinded, multicentre, clinical trial of the efficacy of a $0.1 \%$ PHMB gel (Prontosan ${ }^{\circledR}$ wound gel) to control the bacterial burden in chronic wounds. Patients $(n=142)$ were randomly treated following standard recommendations (control group) or following standard recommendations and $0.1 \%$ PHMB gel additionally (experimental group). After 2 weeks, lesions in the experimental group improved significantly compared to control in terms of reversal of positive cultures $(p=0.004)$, healing process $(p=0.000)$, surface area $(p=0.013)$, granulated tissue percentage $(\mathrm{p}=0.001)$, slough in wound beds $(p=0.002)$, presence of exudates $(p=0.008)$, presence of purulent exudate ( $p=0.005)$, condition of surrounding skin $(\mathrm{p}=0.021)$, pain $(\mathrm{p}=0.049)$, erythema in surrounding skin $(\mathrm{p}=0.004)$, surrounding skin oedema $(\mathrm{p}=0.000)$, surrounding skin warmth $(\mathrm{p}=0.004)$ and odour $(\mathrm{p}=0.029)$.

Roth and Kramer [113] reported supportive antiseptic therapy of chronic ulcus cruris with polihexanide to be successful: in 259 patients with venous ulcera, the average therapy duration covered 4.2 years (min. 4 months, max. 63 years) at the time of first consultation of the pa- 
Table 1. Summaries of some case reports and uncontrolled studies

\begin{tabular}{|c|c|}
\hline Case & Summary \\
\hline $\begin{array}{l}\text { Infected hip } \\
\text { prostheses } \\
{[106]}\end{array}$ & $\begin{array}{l}\text { Patients with infected total hip prostheses were } \\
\text { treated with PHMB in addition to debridement } \\
\text { and systemic antibiotic therapy. Success rate } \\
\text { depended on the local and general conditions and } \\
\text { ranged from } 100 \% \text { ( } 4 \text { patients, contaminated } \\
\text { haematoma) and } 77 \% \text { ( } 18 \text { patients, one-stage } \\
\text { exchange of the prosthesis) to } 20 \% \text { ( } 6 \text { patients, soft } \\
\text { tissue revision without removal of the prosthesis). } \\
\text { Treatment with PHMB was reported to be a useful } \\
\text { supplement to thorough surgical revision }\end{array}$ \\
\hline
\end{tabular}

Infected hip Thirty-one patients after two-stage revision hip prostheses surgery for infection without local antibiotics [107] were monitored clinically and radiologically for 41.3 months. Instead of local antibiotic therapy, a PHMB solution was used for jet lavage of bone and to rinse the surrounding soft tissue.

Re-infection rate was $6.3 \%$. In 9 cases, re-debridements had to be conducted to eradicate infection, but reconstruction of the hips was possible without the use of revision implants or large structured allografts in the majority of cases

Oesophageal A patient with distal oesophageal carcinoma carcinoma presented with dysphagia, dyspnoea, tachycardia, [108] and hypotension. Purulent pericardial and bilateral pleural effusions were successfully treated with antibiotics, repeated pleurocentesis and pericardial drainage with daily PHMB lavage

\begin{tabular}{ll}
\hline MRSA & The first publication that described the complete \\
eradication of MRSA after debridement and \\
application of PHMB gel on the whole \\
circumference of the lower leg within 2 days
\end{tabular}

MRSA A patient with chronic, exudative, therapy[110] resistant ulcers on both lower limbs. MRSA was found in bacteriological smears taken from the ulcers, but no increased inflammation parameters were found in serological tests. After combined surgical and proteolytic debridement, once daily a hydrogel containing 0.1\% PHMB (Prontosan, B. Braun, Germany) was applied. MRSA was successfully eradicated after 8 days of treatment and complete healing of the ecthymata was achieved 9 days later tients. In 192 patients, before the beginning of treatment, a surgical intervention had already been accomplished. Two hundred and ten patients were treated by surgery. All patients were administered local antisepsis with $\mathrm{PHMB}$ (0.04\%)-soaked dressings, partially with previous debridement and following plastic surgery. After 3 days of antiseptic therapy, 72 ulcera $(30.7 \%)$ were bacteriologically negative, after 7 days, 139 (60.1\%). At the time of the check to proof the therapy result, 203 patients (87.8\%) were without recidives. Considering the severity of illness at the beginning of treatment, this is a remarkable result. The microbiological findings and the clinical impression support the assumption that the supportive antiseptic therapy with PHMB contributed considerably to the therapy success.

\section{Additional Clinical Data}

Being such a widely used antiseptic, numerous case reports, letters and short articles have been published on the clinical effect of a variety of formulations containing PHMB in different settings. Table 1 summarizes some of those that are of special interest, because they address problems not yet evaluated in controlled studies.

\section{Discussion}

Infected wounds are still one of the great challenges in medicine. In the last decade, it has become increasingly clear that antimicrobial chemotherapy is limited by the spread of antimicrobial resistance. Additionally, intensive use of antibiotics promotes resistance even further. With the availability of new antiseptic substances with a broad antimicrobial spectrum, provided in easy-to-use and well-tolerated formulations, local treatment is expected to become more and more important in wound therapy.

Polyhexamethylene biguanide, better known as polihexanide or PHMB, is one of the modern antiseptics that combines a broad antimicrobial spectrum with low toxicity, high tissue compatibility, no reported adsorption and good applicability as solution, gel, ointment, foam and in wound dressing. It is actually one of the most promising antiseptic substances. For over 20 years, it has now been used in medicine for many indications including not only the treatment of infected wounds, but Acanthamoeba keratitis, preservation and disinfection of contact lenses, decolonization of skin and mucosa, preoperative eye antisepsis and mouth rinses to name only a few.

Today, PHMB is one of the best investigated antiseptic substances. Its microbicidal effect is based on a strong interaction with negatively charged phospholipids in the bacterial membrane (leading to its disruption) and an inhibition of the bacterial cell metabolism. These two independent and non-specific mechanisms make the development of resistance to PHMB highly unlikely. Actually, 
no bacterial resistance has been described in vitro or from clinical or environmental samples.

Unlike other antiseptics, the antimicrobial efficacy of PHMB is not impaired in human wound fluid, human tissue or by high loads of blood or albumin. This is of utmost importance for the clinical use, because the antimicrobial effect is not limited in the wound. The presence of mucin and chondroitin, on the other hand, abolish the antibacterial effect of PHMB even in low concentrations, as found in nasal and joint fluid. Despite that, a first pilot study using only PHBM-based products for MRSA decolonization (including the nares) interestingly had a success rate of $37 \%$ after single decolonization for 7 days [114]. Due to its mode of action, PHMB needs about $5 \mathrm{~min}$ after application for the full antiseptic effect to occur. Once applied and dispersed in the wound, PHMB binds to cellular surfaces and possesses a sustained effect for hours.

In recent years, it has become more and more evident that microbial biofilms play an important role in many chronic infections. PHMB blocks the microbial attachment to surfaces and has been shown to effectively remove biofilms in vitro and in vivo.

The most interesting feature of PHMB is its outstanding relation between antimicrobial efficacy and low cytotoxicity and exceptional tissue compatibility that has been repeatedly described by independent researchers in vitro, in animal models as well as in controlled clinical studies and case reports. In low concentrations, PHMB even seems to be not only non-toxic, but to have a positive effect on the proliferation of human keratinocytes. This goes well along with animal studies where complete wound closure was achieved significantly earlier using PHMB than placebo and clinical data reporting the same effect in patients with chronic wounds $[106,111,112]$. Because non-healing chronic wounds were shown to have a much higher bacterial load with Pseudomonads (not detectable by cultural methods) compared to healing wounds, the reversal of protein degradation by PHMB could be one clue to its positive effects on wound healing $[23,115]$.

PHMB is not only well tolerated locally, but has an $\mathrm{LD}_{50}$ that makes intoxications unlikely and a therapeutic index that is more than 200-fold that of chlorhexidine (0.9) [59]. Chronic oral intake over 2 years was also tolerated without any adverse reactions [64, 65]. Finally, unlike its sibling chlorhexidine, PHMB seems to carry only a negligible allergic risk.

Despite the large amount of data on PHMB available, some important questions yet have to be answered. As the cytotoxicity and antimicrobial efficacy of PHMB are greatly influenced by additives (intended to reduce the surface tension), further research should be undertaken to find the best combination for clinical use. Furthermore, the optimal concentration, combining the best antimicrobial effect with lowest cytotoxicity, is still to be determined, because the bioavailability in the wound is different to the situation in vitro. Most interestingly, clinical data from case reports seem to indicate that PHBM is not as cytotoxic to serous membranes of humans as data from animal models would suggest. Because to date, no well-described antiseptic exists to be used on the peritoneum, pleura and pericardium, further investigations should focus on the question of whether and under what conditions PHMB would be suitable for this important application.

Until now, a final evaluation of PHMB and other wound antiseptics available is not possible, because independent, well-conducted, controlled, multicentre studies comparing different antiseptics are still not available. Only such studies, in combination with the clinical experience, would provide the evidence necessary to find the optimal antiseptic for the individual patient and situation. Until then, the therapeutic decision for wound therapy should be made based on the data available and the experience of the therapist, and PHMB should in any case be one of the possible choices.

\section{Disclosure Statement}

The authors declare that they have no stocks or stocks options related to any company manufacturing commercially available products on the basis of polihexanide as ingredient. Both authors received consulting fees from B. Braun. Prof. Axel Kramer and Dr. Gerald Müller have a patent pending for a medical device that utilizes polihexanide as active agent. Prof. Axel Kramer received financial support as a clinical investigator for B. Braun, Lohmann \& Rauscher, Serag-Wiesner and Fresenius. Dr. Nils-Olaf Hübner received financial support as a clinical investigator for $\mathrm{B}$. Braun and Serag-Wiesner as well as speaker's honoraria for public medical education related to clinical use of antiseptics, including polihexanide. 


\section{References}

$>1$ Colsky AS, Kirsner RS, Kerdel FA: Analysis of antibiotic susceptibilities of skin wound flora in hospitalized dermatology patients. The crisis of antibiotic resistance has come to the surface. Arch Dermatol 1998;134:10061009.

2 Kramer A, Daeschlein G, Kammerlander G, Andriessen A, Aspöck C, Bergemann R, Eberlein T, Gerngross H, Görtz G, Heeg P, Jünger M, Koch S, König B, Laun R, Peter RU, Roth B, Ruef C, Sellmer W, Wewalka G, Eisenbeiss W: Konsensusempfehlung zur Auswahl von Wirkstoffen für die Wundantiseptik. Hyg Med 2004;5:147-157.

$\checkmark 3$ Ikeda T, Ledwith A, Bamford CH, Hann RA: Interaction of a polymeric biguanide biocide with phospholipid membranes. Biochim Biophys Acta 1984;769:57-66.

$\checkmark 4$ Yasuda K, Ohmizo C, Katsu T: Potassium and tetraphenylphosphonium ion-selective electrodes for monitoring changes in the permeability of bacterial outer and cytoplasmic membranes. J Microbiol Methods 2003; 54:111-115.

$\checkmark 5$ Gabriel GJ, Som A, Madkour AE, Eren T, Tew GN: Infectious disease: connecting innate immunity to biocidal polymers. Mater Sci Eng R Rep 2007;57:28-64.

$\checkmark 6$ Gilbert P, Moore LE: Cationic antiseptics: diversity of action under a common epithet. J Appl Microbiol 2005;99:703-715.

7 Broxton P, Woodcock PM, Gilbert P: Injury and recovery of Escherichia coli ATCC 8,739 from treatment with some polyhexamethylene biguanides. Microbios 1984;40:187193.

8 Broxton P, Woodcock PM, Gilbert P: A study of the antibacterial activity of some polyhexamethylene biguanides towards Escherichia coli ATCC 8739. J Appl Bacteriol 1983; 54:345-353.

$>9$ Ikeda T, Tazuke S, Watanabe M: Interaction of biologically active molecules with phospholipid membranes. 1. Fluorescence depolarization studies on the effect of polymeric biocide bearing biguanide groups in the main chain. Biochim Biophys Acta 1983;735: 380-386.

10 Ikeda T, Tazuke S, Bamford C, Ledwith A: Spectroscopic studies on the interaction of polymeric in-chain biguanide biocide with phospholipid membranes as probed by 8-anilinonaphthalene-1-sulfonate. Bull Chem Soc Jpn 1985;58:705-709.

11 Kramer A, Roth B: Polihexanid; in Kramer A, Assadian O (eds): Wallhäussers Praxis der Sterilisation, Desinfektion, Antiseptik und Konservierung. Stuttgart, Thieme, 2008, pp 789-793.
12 Hansmann F, Kramer A, Ohgke H, Strobel H, Muller M, Geerling G: Lavasept as an alternative to PVP-iodine as a preoperative antiseptic in ophthalmic surgery. Randomized, controlled, prospective double-blind trial. Ophthalmologe 2005;102:1043-1046, 10481050.

13 Rosin M, Welk A, Bernhardt O, Ruhnau M, Pitten FA, Kocher T, Kramer A: Effect of a polyhexamethylene biguanide mouthrinse on bacterial counts and plaque. J Clin Periodontol 2001;28:1121-1126.

14 Körber A, Seipp H, Hofmann S: Efficacy of different wound dressings on artificial plaques of fibrin. EWMA J 2008;8:261.

15 Daeschlein G, Assadian O, Bruck JC, Meinl C, Kramer A, Koch S: Feasibility and clinical applicability of polihexanide for treatment of second-degree burn wounds. Skin Pharmacol Physiol 2007;20:292-296.

16 Kaehn K: Polihexanide: a safe and highly effective biocide. Skin Pharmacol Physiol 2010;23(suppl 1):7-16.

17 Ansorg RA, Azem T, Fabry WH, Rath PM: Influence of mucin on the activity of the antiseptic Lavasept against Staphylococcus aureus. Chemotherapy 2002;48:129-133.

18 Ansorg R, Rath PM, Fabry W: Inhibition of the anti-staphylococcal activity of the antiseptic polihexanide by mucin. Arzneimittelforschung 2003;53:368-371.

19 Muller G, Kramer A: In vitro action of a combination of selected antimicrobial agents and chondroitin sulfate. Chem Biol Interact 2000;124:77-85.

20 Werner H, Kramer A: Mikrobiologische Anforderungen an lokale Antiinfektiva unter spezieller Berücksichtigung der antiinfektiven Wundbehandlung; in Kramer A, Wendt M, Werner H-P (eds): Möglichkeiten und Perspektiven der klinischen Antiseptik. Wiesbaden, mhp, 1995, pp 26-30.

21 Koburger T, Müller G, Eisenbeiss W, Assadian O, Kramer A: Microbicidal activity of polihexanide. GMS Krankenhaushyg Interdiszip 2007;2:Doc44(20071228).

22 Schmidtchen A, Davoudi M, Andersson E: Potent antibacterial effects of polyhexamethylene biguanide on common chronic ulcer-derived bacteria. 13th Annu Conf EWMA, Pisa, 2003.

23 Werthen M, Davoudi M, Sonesson A, Nitsche DP, Morgelin M, Blom K, Schmidtchen A: Pseudomonas aeruginosa-induced infection and degradation of human wound fluid and skin proteins ex vivo are eradicated by a synthetic cationic polymer. J Antimicrob Chemother 2004;54:772-779.

24 Müller G, Kramer A: Biocompatibility index of antiseptic agents by parallel assessment of antimicrobial activity and cellular cytotoxicity. J Antimicrob Chemother 2008;61: 1281-1287.
25 Hübner N, Assadian O, Sciermoch K, Kramer A: Interaktion von Antiseptika und Antibiotika - Grundlagen und erste Ergebnisse in vitro. GMS Krankenhaushyg Interdiszip 2007;2:Doc59(20071228).

26 Hübner N, Kramer A: Antimikrobielle Wirkung und Verträglichkeit von Polihexanid. B Braun Symposium, Baden, 2008.

27 Jethon F, Kramer A (inventors), Fresenius Kabi: Verwendung von PHMB zur Behandlung von durch sich intrazellulär vermehrende Erreger verursachten Infektionen. Eur Patent EP 0788797 A1. 1997.

28 Kramer A, Roth B, Koburger T, Hipler U, Abel M: Polihexanide - Antimicrobial efficacy and biocompatibility. Annu Conf EWMA, Prague, 2006.

29 Müller G, Koburger T, Jethon FU, Kramer A: Comparison of the bactericidal efficacy and in vitro cytotoxicity of Lavasept ${ }^{\circledR}$ and Prontosan ${ }^{\circledR}$. GMS Krankenhaushyg Interdiszip 2007;2:Doc42(20071228).

30 Koburger T, Hübner N-O, Braun M, Siebert J, Kramer A: Standardized comparison of antiseptic efficacy of triclosan, PVP-iodine, octenidine dihydrochloride, polyhexanide and chlorhexidine digluconate. J Antimicrob Chemother 2010, E-pub ahead of print.

31 Messick CR, Pendland SL, Moshirfar M, Fiscella RG, Losnedahl KJ, Schriever CA, Schreckenburger PC: In-vitro activity of polyhexamethylene biguanide (PHMB) against fungal isolates associated with infective keratitis. J Antimicrob Chemother 1999; 44:297-298.

32 Pietsch M, Kraft B: Antimikrobielle Wirksamkeit ausgewählter Substanzen für die Wasserdesinfektion in Dentaleinheiten mit Biofilm. Aseptica 2006;12:3.

33 Harbs N, Siebert J: In vitro efficacy of octenidine and polihexanide against biofilms composed of Pseudomonas aeruginosa. GMS Krankenhaushyg Interdiszip 2007; 2:Doc45(20071228).

34 Willenegger H: Lokale Antiseptika in der Chirurgie - Wiedergeburt und Weiterentwicklung. Unfallchirurg 1994;20:94-110.

35 Krebs FC, Miller SR, Ferguson ML, Labib M, Rando RF, Wigdahl B: Polybiguanides, particularly polyethylene hexamethylene biguanide, have activity against human immunodeficiency virus type 1 . Biomed Pharmacother 2005;59:438-445.

36 Valluri S, Fleming TP, Laycock KA, Tarle IS, Goldberg MA, Garcia-Ferrer FJ, Essary LR, Pepose JS: In vitro and in vivo effects of polyhexamethylene biguanide against herpes simplex virus infection. Cornea 1997;16: 556-559.

37 Seipp H, Hofmann S, Hack A, Skowronsky A, Hauri A: Wirksamkeit verschiedener Wundspüllösungen gegenüber Biofilmen. ZfW 2005;10:160-164. 
38 Brex M, Decker E, Freitag H, Maier G, von Ohle C: The effect of polihexanide on dental biofilm formation in vivo. Pan Eur Federation Int Assoc Dent Res, London, 2008.

39 Behrens-Baumann W, Kramer A: Anti-infectives against amoebic keratitis; in Kramer A, Behrens-Baumann W (eds): Antiseptic Prophylaxis and Therapy in Ocular Infections: Principles, Clinical Practice and Infection Control. Basel, Karger, 2002, pp 297303.

40 Lee JE, Oum BS, Choi HY, Yu HS, Lee JS: Cysticidal effect on acanthamoeba and toxicity on human keratocytes by polyhexamethylene biguanide and chlorhexidine. Cornea 2007;26:736-741.

- 41 Murdoch D, Gray TB, Cursons R, Parr D: Acanthamoeba keratitis in New Zealand, including two cases with in vivo resistance to polyhexamethylene biguanide. Aust NZ J Ophthalmol 1998;26:231-236.

-42 Perez-Santonja JJ, Kilvington S, Hughes R, Tufail A, Matheson M, Dart JK: Persistently culture positive acanthamoeba keratitis: in vivo resistance and in vitro sensitivity. Ophthalmology 2003;110:1593-1600.

-43 Hansmann F, Kramer A, Ohgke H, Strobel $\mathrm{H}$, Muller M, Geerling G: Polyhexamethylbiguanid (PHMB) as preoperative antiseptic for cataract surgery. Ophthalmologe 2004; 101:377-383.

-44 Rosin M, Welk A, Kocher T, Majic-Todt A, Kramer A, Pitten FA: The effect of a polyhexamethylene biguanide mouthrinse compared to an essential oil rinse and a chlorhexidine rinse on bacterial counts and 4-day plaque regrowth. J Clin Periodontol 2002;29: 392-399.

-45 Kramer A, Behrens-Baumann W: Prophylactic use of topical anti-infectives in ophthalmology. Ophthalmologica 1997;211:6876.

46 Rudolph P, Reimer K, Mlynski G, Reese M, Kramer A: Modell zur Ermittlung der Nasenverträglichkeit lokaler Antiinfektiva mittels in-vitro-Bestimmung der Ziliaraktivität. Hyg Med 2000;25:500-503.

$\checkmark 47$ Okano M, Nomura M, Hata S, Okada N, Sato K, Kitano Y, Tashiro M, Yoshimoto Y, Hama R, Aoki T: Anaphylactic symptoms due to chlorhexidine gluconate. Arch Dermatol 1989;125:50-52.

-48 Beaudouin E, Kanny G, Morisset M, Renaudin JM, Mertes M, Laxenaire MC, Mouton C, Jacson F, Moneret-Vautrin DA: Immediate hypersensitivity to chlorhexidine: literature review. Eur Ann Allergy Clin Immunol 2004;36:123-126.

-49 Bergqvist-Karlsson A: Delayed and immediate-type hypersensitivity to chlorhexidine. Contact Dermatitis 1988;18:84-88.

50 Krautheim AB, Jermann TH, Bircher AJ: Chlorhexidine anaphylaxis: case report and review of the literature. Contact Dermatitis 2004;50:113-116.
51 Kanerva L, Elsner P, Wahlberg J, Maibach H: Handbook of Occupational Dermatology. New York, Springer, 2000.

52 De Groot A: Patch Testing. London, Elsevier, 1994.

53 Schnuch A, Geier J, Brasch J, Fuchs T, Pirker C, Schulze-Dirks A, Basketter DA: Polyhexamethylenebiguanide: a relevant contact allergen? Contact Dermatitis 2000;42:302303.

54 Olivieri J, Eigenmann PA, Hauser C: Severe anaphylaxis to a new disinfectant: polihexanide, a chlorhexidine polymer. Schweiz Med Wochenschr 1998;128:1508-1511.

55 Ferrarini A, Baggi M, Fluckiger R, Bianchetti MG: Intraoperative anaphylaxis to a chlorhexdine polymer in childhood. Paediatr Anaesth 2006;16:705.

56 Schnuch A, Geier J, Uter W, Basketter DA, Jowsey IR: The biocide polyhexamethylene biguanide remains an uncommon contact allergen. Contact Dermatitis 2007;56:235239.

57 Freise J, Kohaus S, Korber A, Hillen U, Kroger K, Grabbe S, Dissemond J: Contact sensitization in patients with chronic wounds: results of a prospective investigation. J Eur Acad Dermatol Venereol 2008;22: 1203-1207.

58 Hodge H, Sterner J: Tabulation of toxicity classes. Amer Ind Hyg Ass Quart 1943;10:93.

59 Kramer A, Adrian V, Adam C: Vergleich der Toxizität von Lavasept und ausgewählten Antiseptika. Hyg Med 1993;18:9-16.

60 Langer S, Sedigh Salakdeh M, Goertz O, Steinau HU, Steinstraesser L, Homann HH: The impact of topical antiseptics on skin microcirculation. Eur J Med Res 2004;9:449_ 454.

61 Kramer A: Polihexanid; in Hänsel R, Keller K, Rimpler H, Schneider G (eds): Hagers Handbuch der Pharmazeutischen Praxis. Berlin, Springer, 1994.

62 Frieling H, Lauer KS, Grundling M, Usichenko T, Meissner K, Kanellopoulou T, Lehmann C, Wendt M, Pavlovic D: Peritoneal instillation of taurolidine or polihexanide modulates intestinal microcirculation in experimental endotoxemia. Int J Colorectal Dis 2007;22:807-817.

63 Frieling H, Grundling M, Lauer KS, Wendt M, Hachenberg T, Lehmann C, Pavlovic D: Intraperitoneal instillation of polihexanide produces hypotension and vasodilation: in vivo and in vitro study in rats. Int J Colorectal Dis 2006;21:373-380.

64 Willenegger H: Zum 'Comeback' der lokalen Antiseptika in der Chirurgie. Festvortrag anlässlich der Verleihung der Ehrendoktorwürde der Med. Fak. der Univ.-Gesamthochschule Essen (Germany), 1990.
65 Kramer A, Wallhäusser K: Wirkungsspektrum und Anwendungseigenschaften häufig aus prophylaktischer Indikation angewandter Antiseptika; in Kramer A, Gröschel D, Heeg P, Hingst V, Lippert H, Rotter M, weuffen W (eds): Klinische Antiseptik. Berlin, Springer, 1993, pp 23-82.

66 Fresenius AG: Lavasept-Konzentrat (packaging insert). Fresenius, 1991.

67 EPA, USEPA: Reregistration eligibility decision of PHMB. USEPA, 2005.

68 EPA, Chen J: Evaluation of the carcinogenic potential of PHMB. Office of Prevention, Pesticides, and Toxic Substances, 2003.

69 EPA: Poly(hexamethylenebiguanide) hydrochloride: preliminary risk assessment; notice of availability. Environmental Protection Agency document EPA-HQ-OPP-20040305-001, Federal Register Volume 69 (No 175) 54784-54786. EPA, 2004

70 EPA: Reregistration eligibility decision (RED) for PHMB. Environmental Protection Agency document EPA-HQ-OPP2004-0305-004. EPA, 2004

71 EPA: PC code: 111801. Poly(hexamethylenebiguanide) hydrochloride (PHMB) Case 3122. Toxicology disciplinary chapter for the reregistration eligibility decision document. Environmental Protection Agency document EPA-HQ-OPP-2004-0305-0008. EPA, 2004

72 EPA: Poly(hexamethylenebiguanide) hydrochloride (PHMB): preliminary risk assessment for the reregistration eligibility decision (OPPTS 248.4000). Environmental Protection Agency document EPA-HQ-OPP2004-0305-0004. EPA, 2004.

73 EPA: PHMB summary. Environmental Protection Agency document EPA-HQ-OPP2004-0305-0002. EPA, 2004

74 O'Malley LP, Shaw CH, Collins AN: Microbial degradation of the biocide polyhexamethylene biguanide: isolation and characterization of enrichment consortia and determination of degradation by measurement of stable isotope incorporation into DNA. J Appl Microbiol 2007;103:1158-1169.

75 Zöllner H, Kramer A, Youssef P, Youssef U, Adrian V: Preliminary investigations on the biodegradability of selected microbicidal agents. Hyg Med 1995;20:401-407.

76 Kallenberger A, Kallenberger C, Willenegger $\mathrm{H}$ : Experimentelle Untersuchungen zur Gewebeverträglichkeit von Antiseptika. Hyg Med 1991;16:383-395.

77 Kramer A, Roth B, Koburger T, Hipler U, Abel M: Polihexanide - Antimicrobial efficacy and biocompatibility. Annu Conf EWMA, Prague, 2006.

78 Müller G, Kramer A: Comparative study of in vitro cytotoxicity of povidone-iodine in solution, in ointment or in a liposomal formulation (Repithel) and selected antiseptics. Dermatology 2006;212(suppl 1):91-93. 
79 Hirsch T, Koerber A, Jacobsen F, Dissemond J, Steinau HU, Gatermann S, Al-Benna S, Kesting M, Seipp HM, Steinstraesser L: Evaluation of toxic side effects of clinically used skin antiseptics in vitro. J Surg Res 2009, Epub ahead of print.

80 Wiegand C, Abel M, Ruth P, Hipler U: Polihexanide inhibits the formation of ROS/RNS in vitro. Conférence des plaies et cicatrisations, Paris, 2008.

81 Wiegand C, Abel M, Kramer A, Müller G, Ruth P, Hipler U-C: Stimulation of proliferation and biocompatibility of polihexanide. GMS Krankenhaushyg Interdiszip 2007; 2:Doc43(20071228).

82 Wiegand C, Abel M, Ruth P, Hipler U: Protective effect of polihexanide on HaCaT keratinocytes in co-culture with Staphylococcus aureus. EWMA J 2008;8:178.

$\checkmark 83$ Kalteis T, Luring C, Schaumburger J, Perlick L, Bathis H, Grifka J: Tissue toxicity of antiseptics. Z Orthop Ihre Grenzgeb 2003;141: 233-238.

84 Berg A: Einfluss der peritonealen Spülung mit dem Antiinfektivum Polihexanid/Lavasept auf die experimentell induzierte Peritonitis beim Meerschweinchen; thesis, Greifswald, 2000.

85 Lauenstein P: Untersuchung zur Peritonealverträglichkeit von Polihexanid im Meerschweinchenmodell; thesis, Greifswald 2007.

-86 Ganzer D, Völker L, Follak N, Wolf E, Granzow H: Reaktion des hyalinen Gelenkknorpels und der Synovialis auf eine intraartikuläre Instillation von verschiedenen Antiinfektiva. Arthroskopie 2001;14:31-44.

-87 Kramer A, Roth B, Muller G, Rudolph P, Klocker N: Influence of the antiseptic agents polihexanide and octenidine on FL cells and on healing of experimental superficial aseptic wounds in piglets. A double-blind, randomised, stratified, controlled, parallelgroup study. Skin Pharmacol Physiol 2004; 17:141-146

88 Azuara-Blanco A, Sadiq AS, Hussain M, Lloyd JH, Dua HS: Successful medical treatment of Acanthamoeba keratitis. Int Ophthalmol 1997;21:223-227.

-89 Gray TB, Gross KA, Cursons RT, Shewan JF: Acanthamoeba keratitis: a sobering case and a promising new treatment. Aust NZ J Ophthalmol 1994;22:73-76.

90 Larkin DF, Kilvington S, Dart JK: Treatment of Acanthamoeba keratitis with polyhexamethylene biguanide. Ophthalmology 1992; 99:185-191.
91 Lindquist TD: Treatment of Acanthamoeba keratitis. Cornea 1998;17:11-16.

$\$ 92$ Panda A, Ahuja R, Biswas NR, Satpathy G, Khokhar S: Role of $0.02 \%$ polyhexamethylene biguanide and $1 \%$ povidone iodine in experimental Aspergillus keratitis. Cornea 2003;22:138-141.

$\checkmark 93$ Panda A, Das GK, Biswas NR, Mittal D, Mohanty S: Therapy of acanthamoeba keratitis - an experimental study. Indian J Physiol Pharmacol 2000;44:363-367.

94 Tien SH, Sheu MM: Treatment of Acanthamoeba keratitis combined with fungal infection with polyhexamethylene biguanide. Kaohsiung J Med Sci 1999;15:665-673.

95 Walochnik J, Duchene M, Eibl H, Aspock $\mathrm{H}$ : Treatment of Acanthamoeba keratitis: possibilities, problems, and new approaches. Wien Klin Wochenschr 2003;115:10-17.

$\$ 96$ Seal D: Treatment of Acanthamoeba keratitis. Expert Rev Anti Infect Ther 2003;1: 205-208.

97 Lim N, Goh D, Bunce C, Xing W, Fraenkel G, Poole TR, Ficker L: Comparison of polyhexamethylene biguanide and chlorhexidine as monotherapy agents in the treatment of Acanthamoeba keratitis. Am J Ophthalmol 2008;145:130-135.

98 Elder MJ, Kilvington S, Dart JK: A clinicopathologic study of in vitro sensitivity testing and Acanthamoeba keratitis. Invest Ophthalmol Vis Sci 1994;35:1059-1064.

$\$ 99$ Duguid IG, Dart JK, Morlet N, Allan BD, Matheson M, Ficker L, Tuft S: Outcome of acanthamoeba keratitis treated with polyhexamethyl biguanide and propamidine. Ophthalmology 1997;104:1587-1592.

100 Donoso R, Mura JJ, Lopez M: Acanthamoeba keratitis treated with propamidine and polyhexamethyl biguanide (PHMB). Rev Med Chil 2002;130:396-401. Spanish.

101 Cazzaniga A, Serralta V, Davis S, Orr R, Eaglstein WH, Mertz P: The effect of an antimicrobial gauze dressing impregnated with 0.2-percent polyhexamethylene biguanide as a barrier to prevent Pseudomonas aeruginosa wound invasion. Wounds 2002; 14:169-176.

102 Lee JE, Hahn TW, Oum BS, Choi HY, Yu HS, Lee JS: Acanthamoeba keratitis related to orthokeratology. Int Ophthalmol 2007; 27:45-49.

103 Jeong HJ, Lee SJ, Kim JH, Xuan YH, Lee KH, Park SK, Choi SH, Chung DI, Kong HH, Ock MS, Yu HS: Acanthamoeba: keratopathogenicity of isolates from domestic tap water in Korea. Exp Parasitol 2007;117: 357-367.
104 Lin JC, Ward TP, Belyea DA, McEvoy P, Kramer KK: Treatment of Nocardia asteroides keratitis with polyhexamethylene biguanide. Ophthalmology 1997;104:13061311.

105 Fiscella RG, Moshifar M, Messick CR, Pendland SL, Chandler JW, Viana M: Polyhexamethylene biguanide (PHMB) in the treatment of experimental Fusarium keratomycosis. Cornea 1997;16:447-449.

106 Schmit-Neuerburg K, Bettag C, Schlickewei W, Fabry W, Hanke J, Renzig-Köhler K, Hirche H, Kock HJ: Wirksamkeit eines neuartigen Antiseptikum in der Behandlung kontaminierter Weichteilwunden. Chirurg 2001;72:61-71.

107 Roth B, Baltzer K: Preventive intraoperative irrigation in wound management with Lavasept. Report of experiences with 1,610 cases. Z Unfallchir Versicherungsmed 1990;83:224-226.

108 Roth B, Baltzer K: Preliminary treatment of the recipient site and healing of open spongiosa transplant in post-traumatic osteitis. Helv Chir Acta 1989;56:571-572.

109 Roth B: Erfahrungen mit dem Einsatz von Polihexanid in der chirurgischen Praxis. Proc B Braun Symp, Baden, 2008.

110 Roth B, Assadian O, Wurmitzer F, Kramer A: Surgical site infections after primary antiseptic cleansing of dirty-contaminated wounds by polihexanide, PVP iodine resp hydrogen peroxide. GMS Krankenhaushyg Interdiszip 2007;2:Doc58(20071228).

111 Andriessen A, Eberlein T: Assessment of a wound cleansing solution in the treatment of problem wounds. Wounds 2008;20:171175.

112 Valenzuela A, Perucho N: The effectiveness of a $0.1 \%$ polihexanide gel. Rev Endferm 2008;31:7-12.

113 Roth B, Kramer A: Supportive antiseptic therapy of chronic ulcus cruris with polihexanide. GMS Krankenhaushyg Interdiszip 2009;4:Doc16(20091216).

114 Harbarth S: Pilot Study on the MRSA Decolonisation with PHMB-Based Products. 2006, personal communication.

115 Davies CE, Hill KE, Wilson MJ, Stephens P, Hill CM, Harding KG, Thomas DW: Use of 16S ribosomal DNA PCR and denaturing gradient gel electrophoresis for analysis of the microfloras of healing and nonhealing chronic venous leg ulcers. J Clin Microbiol 2004;42:3549-3557. 